\title{
PROSES MEDIASI DALAM MENCEGAH TERJADINYA PERCERAIAN DI PENGADILAN AGAMA
}

\author{
Novi Hidayati Afsari, Ineu Yuni Andini \\ Bimbingan Penyuluhan Islam STID Sirnarasa \\ xanovha@gmail.com.
}

\begin{abstract}
ABSTRAK
Mediasi adalah proses penyelesaian sengketa melalui perundingan pihak ketiga (mediator) yang netral tidak memihak, tidak bekerja dengan pihak yang bersengketa, membantu yang bersengketa mencapai kesepakatan hasil negosiasi yang memuaskan. Salah satu sengketa yang terjadi yaitu perceraian, mediasi perceraian /ialah suatu upaya yang dilakukan Pengadilan Agama untuk menekan tingginya angka perceraian. Tingginya angka perceraian di daerah kabupaten Ciamis merupakan suatu permasalahan yang sangat sulit di selesaikan dengan cara kekeluargaan. Untuk itulah perlu adanya mediasi sebagai upaya preventif dalam mencegah terjadinya perceraian. Penelitian ini, bertujuan untuk mengetahui bagaimana proses mediasi perceraian dalam mencegah perceraian di Pengadilan Agama Kelas 1-A Ciamis Jawa Barat. Penelitian yang digunakan adalah metode analisis kualitatif yaitu apa yang dinyatakan oleh responden secara tertulis mupun lisan dan perilaku yang nyata diteliti sebagai sesuatu yang utuh.Hasil dari penelitian yang penulis lakukan di Pengadilan Agama Kelas 1A Tanjung karang ialah bahwa mediasi bukanlah sekedar formalitas saja yang harus dilalui dalam proses perceraian, akan tetapi dalam proses mediasi serta faktor pendukung dan penghambat yang mempengaruhi mediator dalam proses mediasi, Hakim Mediator bersungguh-sungguh mengupayakan pihak yang bersengketa baik suami ataupun istri yang ingin bercerai untuk bisa menyelesaikan masalah yang mereka hadapi melalui proses mediasi yang diatur dalam PERMA Nomor 1 Tahun 2016.
\end{abstract}

Kata kunci: Mediasi, Pengadilan Agama 


\section{PENDAHULUAN}

Pernikahan dalam Islam yaitu untuk membentuk keluarga sebagai sarana untuk meraih kebahagiaan hidup. Di Indonesia terdapat hukum positif yang mengatur pernikahan, yaitu Undang-Undang No.1 Tahun 1974 yang menyebutkan 'bahwa pernikahan ialah ikatan lahir dan batin antara seorang pria dan wanita sebagai suami istri dengan tujuan membentuk keluarga (rumah tangga) yang bahagia dan kekal berdasarkan Ketuhanan yang Maha Esa.',

Definisi di atas dapat di rinci akan di temukan:

1. Pernikahan ialah ikatan lahir batin antara seorang pria dan seorang wanita sebagai suami istri.

2. Ikatan lahir batin itu untuk membentuk keluarga (rumah tangga) yang bahagia dan sejahtera.

3. Dasar ikatan lahir batin dan tujuan bahagia yang kekal itu berdasarkan pada Ketuhanan Yang Maha Esa.

Sebelum pernikahan berlangsung biasanya orang membayangkan kehidupan yang bahagia hanya sekedar melepas nafsu biologis dan mengikat hubungan yang sah, akan tetapi tidak memikirkan permasalah hidup dan seringkali diabaikan oleh para calon pasangan suami istri terutama kaum muda. Mereka sering mengabaikan faktor psikologis, penghasilan dan yang paling penting ialah faktor kedewasaan dari masing-masing pihak. Perjalanan kehidupan rumah tangga pada umumnya baik yang muda maupun yang dewasa seringkali dimulai dengan adanya masalah (Nusyuz/I'rad) diteruskan dengan pertengkaran atau permasalahan lainnya seperti faktor ekonomi, pekerjaan, pembagian tugas yang tidak sesuai dengan keinginan masing-masing, bahkan adanya perselingkuhan dan lain sebagainya.

Di Indonesia terjadi peningkatan perceraian dari tahun ke tahun tidak terkecuali di kabupaten Ciamis. Dari tahun 2012 hingga 2015 kasus perceraian di wilayah Ciamis rata rata terjadi sekitar 400 kasus perbulan. Angka perceraian tersebut berada diposisi ke 4 di Jawa Barat setelah Indramayu, Sumber (Cirebon) dan Cimahi. Sepanjang tahun 2016 tercatat hanya sekitar 3000 kasus perceraian ${ }^{1}$. Pada tahun 2017 sendiri kasus perceraian meningkat di kabupaten Ciamis sendiri kasus perceraian kembali meningkat, Pengadilan Agama Ciamis mencatat dari bulan Januari sampai Juni 2017 sebanyak 2.054 perkara perceraian sudah masuk dalam rekapitulasi. Angka tersebut terbilang cukup tinggi apabila dibanding tahun sebelumnya.

Sementara untuk tahun 2017, baru di pertengahan tahun saja sudah menembus angka 2000 kasus perceraian. Dari 2.054 kasus perceraian, baru sekitar 1700 yang sudah diputus resmi bercerai, sementara sisanya masih dalam proses di pengadilan agama. Sedangkan dari 2.054 kasus perceraian, 1.342 diantaranya gugat cerai atau istri yang menggugat suami. Sedangkan sisanya yakni 712 kasus cerai talak atau suami menceraikan istri. Dari total angka kasus gugat cerai tersebut, maka rata-rata ada sekitar 343 kasus perbulan. Penyebab utama terjadinya perceraian di Ciamis diantara nya faktor ekonomi, ketidak cocokan, hingga adanya orang ketiga.

Menurut Penjelasan Pasal 39 ayat (2) Undang-undang Perkawinan terdapat beberapa hal yang dapat dijadikan sebagai alasan untuk mengajukan perceraian, yaitu:

1. Salah satu pihak berbuat zina atau menjadi pemabuk, pemadat, penjudi dan lain sebagainya yang sukar disembuhkan.

2. Salah satu pihak meninggalkan yang lain selama dua tahun beturut-turut tanpa alasan yang sah atau karena hal lain diluar kemampuannya.

3. Salah satu pihak mendapat hukuman penjara 5 (lima) tahun atau hukuman yang lebih berat 
selama perkawinan berlangsung.

4. Salah satu pihak mendapat cacat badan atau penyakit yang mengakibatkan tidak dapat menjalankan kewajibannya sebagai suami atau istri.

5. Salah satu pihak melakukan kekejaman atau penganiayaan berat yang membahayakan terhadap pihak lain.

6. Antara suami dan isteri terus-menerus terjadi perselisihan dan pertengkaran dan tidak ada harapan akan hidup rukun dalam rumah tangga.

\section{KAJIAN PUSTAKA}

\section{Pengertian Konseling Keluarga}

Family counseling atau konseling keluarga adalah upaya bantuan yang diberikan kepada individu anggota keluarga melalui system keluarga (pembenahan komunikasi keluarga) agar potensinya berkembang seoptimal mungkin dan masalahnya dapat diatasi atas dasar kemauan membantu dari semua anggota keluarga berdasarkan kerelaan dan kecintaan terhadap keluarga

Menurut Perez (1979:19) mengemukan sebagai berikut:

"it is system approach to family theraphy which is very much in vogue. This approach focuses on the family current problem (the now is the issue) how family members interaction closely observed by system therapist, neurosis, even psychosis in a member of family is viewed as afunction of the interaction between and among the various family members. The belief is that an individual lil health ia the result of his adaptation to the sick environment created by the family".

Dari pernyataan diatas dapat di tarik kesimpulan yang mana sakitnya seorang anggota keluarga adalah merupakan hasil adaptasi atau interaksinya terhadap lingkungan yang sakit pula yang diciptakan oleh keluarga itu.

Beberapa pengertian tentang konseling keluarga yang dikemukakan oleh beberapa tokoh antara lain seperti Golden dan Sherwood (dikutip dari Latipun, 2001) konseling keluarga adalah metode yang dirancang dan difocuskan pada keluarga dalam usaha untuk membantu memecahkan masalah perilaku klien. Masalah ini pada dasarnya bersifat pribadi karena dialami oleh klien sendiri. Akan tetapi, konselor menganggap permasalahan yang dialami klien tidak semata disebabkan oleh klien sendiri melainkan dipengaruhi oleh system yang terdapat dalam keluarga klien sehingga keluarga diharapkan ikut serta dalam menggali dan menyelesaikan masalah klien.

Dengan memahami makna dari Konseling Keluarga maka semakin jelas bahwa konseling keluarga menekankan permasalahan klien sebagai masalah "system" yang ada dalam keluarga sehingga memandang klien sebagai bagian dari kelompok tunggal atau satu kesatuan dengan keluarganya.

Dengan kata lain konseling keluarga sangat dibutuhkan bagi individu yang tidak dapat memecahkan masalah yang sedang dihadapinya, maka perlu bantuan orang lain atau bimbingan konseling keluarga yang berperan membantu mengarahkan ataupun memberikan pandangan kepada individu yang bersangkutan. Apalagi sekarang ini perkembangan masyarakat sangat mempengaruhi pola kehidupan seseorang baik sebagai individu maupun anggota masyarakat. Individu saat ini dihadapkan pada perubahan-perubahan yang begitu kompleks, sehingga menimbulkan berbagai macam tantangan atau tuntutan terhadap kebutuhan individu.

1. Tujuan Konseling Keluarga 
Secara garis besar tujuan konseling keluarga dapat dibagi menjadi dua yaitu, tujuan umum dan tujuan khusus antara lain sebagai berikut:

a. Tujuan umum konseling keluarga

1) Membantu anggota-anggota keluarga belajar dan menghargai secara emosional bahwa dinamika keluarga adalah kait-mengait di antara anggota keluarga.

2) Untuk membantu anggota keluarga agar menyadari tentang fakta jika satu anggota bermasalah, maka akan mempengaruhi kepada presepsi, ekspektasi, dan interaksi anggota-anggota lain.

3) Agar tercapai keseimbangan yang akan membuat pertumbuhan dan peningkatan setiap anggota.

4) Untuk mengembangkan penghargaan penuh sebagai pengaruh dari hubungan parental.

b. Tujuan tujuan khusus konseling keluarga

1) Untuk meningkatkan toleransi dan dorongan anggota-anggota keluarga terhadap cara-cara yang istimewa (idiocyncratic ways) atau keunggulan-keunggulan anggota lain.

2) Mengembangkan toleransi terhadap anggota-anggota keluarga yang mengalami frustasi/kecewa, konflik, dan rasa sedih yang terjadi karena factor system keluarga atau di luar system keluarga.

3) Mengembangkan motif dan potensi-potensi, setiap anggota keluarga dengan cara mendorong (men-support), memberi semangat, dan mengingat anggota tersebut.

4) Mengembangkan keberhasilan persepsi diri orang tua secara realistic dan sesuai dengan anggota-anggota lain.

\section{Pengertian Mediasi}

Secara etimilogi, istilah mediasi berasal dari bahasa latin, mediare yang berarti berada di tengah. Maka ini menunjukkan pada peran yang ditampilkan pihak ketiga sebagai mediator dalam menjalankan tugasnya menengahi dan menyelesaikan sengketa. Mediator harus mampu menjaga kepentingan para pihak yang bersangketa secara adil dan sama, sehingga menimbulkan kepercayaan dari pihak yang bersengketa.

Mediasi berasal dari kata "media" yang berarti perantara atau penghubung. Dengan demikian mediasi berarti kegiatan mengantari atau menghubungkan dua hal terpisah, menjalin hubungan antara dua hal kondisi yang berbeda, mengadakan kontak sehingga dua yang semula tidak sama menjadi saling terkait secara positif. Dengan adanya perantara atau penghubung, kedua hal yang tadinya terpisah itu saling terkait dan saling mengambil manfaat dari adanya perantara atau penghubung untuk keuntungan keduanya.

Layanan mediasi merupakan layanan konseling yang dilaksanakan konselor terhadap dua pihak (atau lebih) yang sedang dalam keadaan saling tidak menemukan kecocokan. Ketidakcocokan itu menjadikan mereka saling berhadapan saling bermusuhan. Pihak-pihak yang berhadapan itu jauh dari rasa damai, bahkan mungkin berkehendak saling menghancurkan. Keadaan yang demikian itu akan merugikan kedua pihak (atau lebih). Dengan layanan mediasi konselor berusaha mengantari atau membangun hubungan diantara mereka, sehingga mereka menghentikan dan terhindar dari pertentangan lebih lanjut yang merugikan semua pihak

Dalam PERMA Nomor 1 tahun 2016 disebutkan pengertian mediasi adalah cara penyelesaian sengketa melalui proses perundingan untuk memperoleh kesepakatan para pihak dengan dibantu oleh mediator

Adapun Noland Harley Mendefinisikan mediasi sebagai

"Medisiation is a short term structured task oriented, partipatory invention pricess. Disputing parties work with a neutral third party, the mediator, to reach a mutually acceptable agreement". 
Yang dimaksud oleh Noland Harley yaitu Mediasi adalah proses penemuan jangka pendek yang terstruktur berorientasi, Pihak yang bersangkutan bekerja dengan pihak ketiga yang netral, (Mediator) untuk mencapai kesepakatan yang dapat diterima bersama

Dalam Al-Quran menyebutkan bahwa layanan mediasi adalah layanan yang membantu klien dalam menyelesaikan permasalahan dan memperbaiki hubungan antar mereka. Sebagaimana firman Allah menjelaskan dalam surat An-Nisa: 35

Yang artinya:

Dan jika kamu khawatirkan ada persengketaan antara keduanya, Maka kirimlah seorang hakam dari keluarga laki-laki dan seorang hakam dari keluarga perempuan. Jika kedua orang hakam itu bermaksud mengadakan perbaikan, niscaya Allah memberi taufik kepada suami-isteri itu. Sesungguhnya Allah Maha mengetahui lagi Maha Mengenal.

Menurut John W. Head mediasi adalah

Suatu prosedur penengah dimana seorang bertindak sebagai "kendaraan" untuk berkomunikasi antar para pihak, sehingga pandangan mereka berbeda atas sengketa tersebut dapat dipahami dan mungkin didamaikan, tetapi tanggung jawab utama tercapainya suatu perdamaian tetap berada ditangan pihak sendiri. Dalam definisi tersebut, mediator dianggap sebagai "kendaraan" bagi para pihak untuk berkomunikasi.

Berdasarkan teori di atas dapat disimpulkan bahwa layanan mediasi yaitu salah satu layanan dalam bimbingan dan konseling yang dilakukan oleh seorang mediator sebagai penengah terhadap pihak yang bertikai atau sedang tidak menemukan kecocokan. Sehingga ketidakcocokan itu menjadikan mereka saling berhadapan, saling bermusuhan ketidakdamaian atau kerukunan yang dapat menyebabkan kerugian diantara pihak yang bertikai.

Mediasi juga wajib dilakukan oleh para pihak yang berperkara secara perdata di Pengadilan yang dilakukan pada hari sidang pertama. Kemudian setelah proses mediasi ditempuh, maka mereka wajib menghadap kembali pada hakim pada sidang yang ditentukan dan jika para pihak mencapai kesepakatan, maka mereka dapat meminta penetapan dengan suatu akta perdamaian. Namun, jika kesepakatan tidak tercapai maka mediator wajib menyatakan secara tertulis bahwa proses mediasi gagal dan selanjutnya sidang dilanjutkan sebagaimana acara sidang biasa

\section{Mediasi dalam Islam}

Konsep Penyelesaian sengketa Melalui mediasi yang menggunakan win win solution atau penyelesaian menang sama menang, telah lama dikenal dalam hukum adat indonesia. Konsep penyelesaian sengketa melalui musyawarah antara para pihak telah lama dikenal oleh masyarakat hukum adat, penyelesaian sengketa menurut hukum adat selalu diarahkan kepada pemulihan dan keseimbangan tatanan yang terganggu karena adanya sengketa tersebut, dan tidak bersifat adanya penghukuman.

Konsep penyelesaian sengketa win win solution seperti dalam mediasi, juga dikenal dalam sistem hukum islam.walaupun tidak disebut dalam mediasi, namun pola penyelesaian sengketa yang digunakan menyerupai pola yang digunakan dalam mediasi. Dalam sistem hukum Islam dikenal dengan apa yang disebut istilah islah dan hakam.

Islah adalah ajaran Islam yang bermakna lebih menonjolkan metode penyelesaikan perselisihan atau konflik secara damai dengan mengesampingkan perbedaan perbedaan yang menjadi akar perselisihan. Intinya bahwa para pihak yang berselisih diperintahkan untuk mengikhlaskan "kesalahan" masing masing dan diamalkan untuk saling memaafkan.

Pengertian islah juga sangat berkembang penggunaanya dikalangan masyarakat Islam secara luas, baik untuk menyelesaikan kasus kasus perselisihan ekonomi bisnis maupun nonekonomi-bisnis. Contohnya, sewakttu terjadi perselisihan paham antara dua tokoh Islam, yaitu dan Abdurahman Wahid dengan Abu Hasan, hampir semua pemuka agama Islam 
mengajukan keduanya untuk ber islah. Konteks Islah dapat diidentikan dengan pengertian mediasi atau konsiliasi.

Selain Islah di kenal juga istilah Hakam.Hakam mempunyai pengertian yang sama dengan mediasi. Dalam sistem hukum Islam hakam biasanyaberfungsi untuk menyelesaikan perselisihan perkawinan yang disebut dengan syiqaq. Mengenai pengertian hakam, para ahli hukum islam memberikan pengertian yang berbeda - beda namun, dari pengertian yang berbeda beda tersebut dapat disimpulkan bahwa hakam merupakan pihak ketiga yang mengikatkan diri kedalam knflik yang terjadi diantara suami istri sebagai pihak yang menegahi atau menyelesaikan sengketa diantara mereka.

Sebagai pedoman pengertian hakam diambil dari penjelasan pasal 76 ayat (2) UndangUndang Nomor 7 Tahun 1989. Undang-Undang Nomor 3 Tahun 2006, Undang-Undang Nomor 50 Tahun 2009 tentang peradilan Agama. Dikatakan bahwa

"Hakam adalah orang yang ditetapkan pengadilan dari pihak keluarga suami atau pihak keluarga istri atau pihak lain untuk mencari upaya penyelesaian perselisihan terhadap syiqaq".

Dari bunyi penyelesaian tersebut dapat disimpulkan bahwa fungsi / hakam hanyalah untuk mencari upaya penyelesaian perselisihan, bukan untuk menjatuhkan keputusan.

Dengan demikian, kita lihat bahwa hakam dalam islam ini mempunyai kesamaan dengan mediator. Keduanya (baik mediator maupun hakam) tidak mempunyai kewenangan untuk memutus. Keduanya merupakan mekanisme penyelesaian sengketa diluar pengadilan yang dilakukan oleh pihak ke tiga.

\section{Perceraian}

Menurut Bahasa Arab perceraian berasal dari kata Talaq atau Itlaq yang artinya lepas dari ikatan, berpisah menceraikan, pembebasan. Perceraian menurut Kamus Bahasa Indonesia disebut "cerai" yang artinya pisah, terpisah antara suami dan istri

Perceraian menurut Gunarsa adalah pilihan paling menyakitkan bagi pasangan suami dan istri, namun demikian perceraian bisa jadi pilihan terbaik yang bisa membukakan jalan terbaik bagi kehidupan yang membahagiakan. Perceraian mengakibatkan status seorang lakilaki sebagai suami maupun status seorang perempuan sebagai istri akan berakhir, namun perceraian tidaklah menghentikan status mereka masing-masing sebagai ayah dan ibu terhadap anak-anak yang telah dilahirkan.

Perceraian menurut Undang-Undang Republik Indonesia pasal 39 No.1 tahun 1974 maka dasar hukum perceraian dikatakan bahwa:

a. Perceraian dapat dilakukan di depan sidang pengadilan yang bersangkutan berusaha dan tidak berhasil mendamaikan kedua belah pihak.

b. Untuk melakukan perceraian harus ada cukup alasan, bahwa antara suami istri tidak akan hidup rukun sebagai suami istri.

c. Tata cara perceraian di depan sidang pengadilan diatur dalam peraturan perundangan tersebut.

Pengertian di atas dapat disimpulkan bahwa perceraian adalah putusnya hubungan pernikahan karena kehendak kedua belah pihak, yang dilakukan atas kehendak suami atau istri berdasarkan putusan pengadilan yang mengakibatkan status suami atau istri berakhir. Perceraian diakibatkan karena kegagalan dalam mencapai tujuan pernikahan yang bahagia, kekal, dan sejahtera.

\section{Perceraian dan Mediasi di Pengadilan Agama}

Menurut Pasal 38 UU perkawinan No.1 Tahun 1974, perkawinan dapat putus karena kematian, perceraian dan atas keputusan pengadilan. Putusnya perkawinan yang disebabkan karena perceraian dapat terjadi karena talak atau berdasarkan gugatan perceraian. Dalam UU 
No. 7 Tahun 1989 tentang Peradilan Agama, istilah perceraian telah dibedakan ke dalam 2 (dua) bentuk yakni cerai talak dan cerai gugat. Cerai talak adalah perceraian dalam bentuk talak yang datang dari pihak suami. Sedangkan cerai gugat adalah perceraian yang diajukan oleh pihak isteri. Undang-Undang membedakan antara perceraian atas kehendak istri dikarenakan karakteristik hukum Islam dalam perceraian memang menghendaki demikian. Sehingga proses perceraian atas kehendak suami berbeda dengan proses perceraian atas kehendak isteri.

\section{METODE PENELITIAN}

Jenis penelitian yang digunakan dalam menganalisis data adalah dengan menggunakan metode analisis kualitatif. Analisis kualitatif adalah suatu cara penelitian yang menghasilkan data deskriptif analisis, yaitu apa yang dinyatakan oleh responden secara tertulis serta lisan dan juga perilaku yang nyata diteliti sebagai sesuatu yang utuh.

\section{HASIL DAN PEMBAHASAN}

\section{Sejarah Berdirinya Pengadilan Agama Ciamis kelas1-A}

Sejak pemerintahan Belanda berkuasa abad ke-19, maka dalam sistem perundangundangan dulu peradilan agama termasuk dalam lingkungan peradilan swapraja dan lingkungan peradilan adat, bahkan kadang-kadang berdiri ataupun dilakukan dalam kedua peradilan ini dan disamping itu adapula yang berada dalam lingkungan peradilan Gubernemen yaitu yang ada di Jawa dan Madura.

Kemudian pada tahun 1882 dengan Staatblad no. 152 diaturlah peradilan yang disebut Priestraad atau biasanya masyarakat mengenalnya sebagai raad agama, yang berkedudukan dimana ada landraad, kemudian disusul dengan staatblad 1397 no. 116 dan 610, demikian zaman pendudukan penjajahan Jepang, hal ini berarti disebabkan dia telah berurat barakat dalam kehidupan masyarakat Indonesia, sehingga dengan demikian kenyataannya perkembangan peradilan agama pada waktu itupun tidak dapat diabaikan.

Sejalan dengan ketentuan Pasal 24 ayat (1 dan 2) Undang-Undang Dasar 1945 Pemerintah telah menetapkan Undang-Undang nomor 4 Tahun 1970 yang telah diubah dengan Undang-Undang nomor 4 Tahun 2004 tentang Kekuasaan Kehakiman yang merupakan dasar-dasar serta asas-asas peradilan, sekaligus pedoman bagi semua lingkungan peradilan, baik peradilan umum, peradilan agama, peradilan militer maupun tata us aha negara yang masing-masing lingkungan diatur dalam Undang-Undang.

Pengadilan Agama Ciamis yang merupakan salah satu badan peradilan agama yang berkedudukan dan berada di Kabupaten Ciamis, yang wilayah hukumnya termasuk Kota Banjar sehingga dalam perkembangan sejarahnya sejak berdiri hingga sekarang tidak terlepas dari ketentuan dan keadaan tersebut diatas.

Bahwa Pengadilan Agama Ciamis sejak berdirinya di Kabupaten Ciamis berkantor di Komplek Mesjid Agung Ciamis tepatnya di J1. Ir. H. Juanda Kelurahan Ciamis, Kecamatan Ciamis, Kabupaten Ciamis dengan Ketuanya yaitu K.H. Zaenal Abidin dan K.H.R.M. Wardi. Kemudian pada tahun 1962 Pengadilan Agama Ciamis berpindah tempat ke Komplek Perkantoran Departemen Agama Kabupaten Ciamis yang berlokasi di Jl. Ahmad Yani No. 53 Ciamis yang sekarang dijadikan sebagai Gedung Arsip. Pada masa tersebut kepemimpinan di Pengadilan Agama Ciamis mengalami beberapa kali pergantian kepemimpinan yaitu dimulai oleh K.H.M. Subki, K.H.R. Ma'mun, K.H. Ahmad Aos dan Drs. H. Oman Abdurahman serta Drs. H. Sualim.

Pada masa kepemimpinan Drs. H. Sualim yaitu sekitar tahun 1980, Pengadilan Agama Ciamis mendapatkan sarana tanah untuk perkantoran dari Pemerintah Kabupaten Ciamis yang berlokasi di J1. Ir. H. Juanda no. 272 Ciamis dan di bangun Gedung Kantor Pengadilan Agama Ciamis

Pada tanggal 09 Juni 2003 berkat dukungan dari DPRD Kabupaten Ciamis juga Ketua MUI Kabupaten Ciamis almukarom K.H. Irfan Hilmi (pengasuh Ponpes Darussalam Ciamis), 
Pemerintah Kabupaten Ciamis menerbitkan Surat Keputusan Bupati nomor 593/Kpts.157Huk/2003, Pengadilan Agama Ciamis mendapatkan fasilitas tanah untuk gedung baru seluas 3.282 M2 yang kemudian dibangun Gedung Kantor Pengadilan Agama Ciamis melalui proses 3 (tiga) tahap, yaitu :

Tahap I Tahun 2006, sumber dana DIPA Pengadilan Agama Ciamis Tahun Anggaran 2006 jumlah dana Rp 2.000.000.000,- (dua milyar rupiah), dana yang terserap Rp 1.987.651.140,- (satu milyar sembilan ratus delapan puluh tujuh juta enam ratus lima puluh satu ribu seratus empat puluh rupiah) dengan sisa dana Rp 12.348.860,- (dua belas juta tiga ratus empat pululh delapan ribu delapan ratus enam puluh rupiah).

Tahap II Tahun 2007, sumber dana DIPA Pengadilan Agama Ciamis Tahun Anggaran 2007 jumlah dana Rp 3.473.710.000,- (tiga milyar empat ratus tujuh puluh tiga juta tujuh ratus sepuluh ribu rupiah), dana yang terserap Rp 3.473.293.970,- (tiga milyar empat ratus tujuh puluh tiga juta dua ratus sembilan puluh tiga ribu sembilan ratus tujuh puluh rupiah) dengan sisa dana $\mathrm{Rp} 416.030$,- (empat ratus enam belas ribu tiga puluh rupiah).

Tahap III Tahun 2008 merupakan tahap Pengadaan Meubelair, sumber dana DIPA Pengadilan Agama Ciamis Tahun Anggaran 2008 jumlah dana Rp 965.000.000,- (sembilan ratus enam puluh lima juta rupiah), dana yang terserap Rp 910.053.000,- (sembilan ratus sepuluh juta lima puluh tiga ribu rupiah) dengan sisa dana Rp 54.947.000,- (lima puluh empat juta sembilan ratus empat puluh tujuh ribu rupiah). Bangunan gedung tersebut diresmikan pada hari Kamis tanggal 03 Juli 2008 bertepatan dengan tanggal 29 Jumadits Tsani 1429 H oleh Ketua Mahkamah Agung RI yaitu Prof. DR. H. Bagir Manan, SH.,MCL. Sejak diresmikannya gedung tersebut, maka Kantor Pengadilan Agama Ciamis pindah ke alamat Jl. RAA. Sastrawinata No. 2 Ciamis sampai sekarang.

VISI DAN MISI

\section{VISI \\ “TERWUJUDNYA PENGADILAN AGAMA CIAMIS YANG AGUNG" MISI}

\section{1) Meningkatkan kepercayaan masyarakat terhadap sistem peradilan}

Proses peradilan yang pasti, transparan dan akuntabel merupakan faktor penting untuk meningkatkan kepercayaan pencari keadilan kepada badan peradilan. Upaya untuk meningkatkan kepercayaan pencari keadilan akan dilakukan dengan mengefektifkan proses peradilan yang pasti, transparan dan akuntabel melalui penyempurnaan pelayanan berbasis teknologi, penataan ulang manajemen perkara, dan transparansi kinerja melalui manajemen perkara berbasis Informasi Teknologi.

\section{2) Mewujudkan Pelayanan Prima Bagi Masyarakat Pencari Keadilan}

Tugas badan peradilan adalah menyelenggarakan peradilan guna menegakkan hukum dan keadilan. Menyadari hal ini, orientasi perbaikan yang dilakukan Mahkamah Agung mempertimbangkan kepentingan pencari keadilan dalam memperoleh keadilan adalah keharusan bagi setiap badan peradilan untuk meningkatkan pelayanan publik dan memberikan jaminan proses peradilan yang adil.

\section{3) Meningkatkan Akses Masyarakat Terhadap Keadilan}

Bagi masyarakat miskin untuk mendapatkan pelayanan tidak mampu membayar pendamping sehingga tidak jarang mereka tidak mendapatkan keadilan itu sendiri ditambah lokasi tempat tinggal yang tidak terjangkau. Pengadilan Agama Ciamis melalui mekanisme bantuan hukum berupaya memfasilitasi masyarakat miskin tersebut dengan meningkatkan akses peradilan melalui pembebasan biaya perkara, sidang keliling/zitting plaats dan pos layanan hukum (posyankum).

\section{Aktivitas Mediasi}


Mediasi di Pengadilan Agama Ciamis kelas 1-A sudah diterapkan sejak awal berdirinya Pengadilan Agama dan sejak dikeluarkannya PERMA No. 1 Tahun 2008 tentang Prosedur Mediasi di Pengadilan. Dengan adanya dilaksanakan mediasi ini, diharapkan setiap pengadilan dapat mengurangi penumpukan perkara.

Hal ini diungkap oleh Bapak Drs. Oman, S.Ag Hakim mediator di Pengadilan Agama Ciamis.

Mediasi itu baik untuk dilakukan terlebih dulu sebelum perkara diperiksa oleh hakim. Mediasi baik untuk ditempuh karena memiliki berbagai macam keuntungan dalam pelaksanaannya diantaranya proses penyelesaiannya lebih cepat daripada litigasi, biaya relatif murah, hubungan kekeluargaan tetap terjaga, dan sebagainya. Sedangkan dalam litigasi prosesnya panjang, biaya mahal, serta keputusannya akan bercorak menang dan kalah. Mediasi dapat dilaksanakan dengan bantuan/ menunjuk hakim mediator dalam daftar mediator di Pengadilan Agama Ciamis maupun menunjuk mediator diluar hakim

Pada hari sidang pertama, kehadiran para pihak yang berperkara sangat diharapkan karena saat itulah kesempatan oleh ketua majelis hakim memberikan saran melakukan perdamaian kepada kedua belah pihak, dengan kata lain ketua majelis hakim akan menawarkan para pihak untuk menempuh proses mediasi. Jika para pihak telah sepakat untuk menempuh proses mediasi maka, ketua majelis akan memberikan kewenangan kepada para pihak untuk memilih mediator yang mereka kehendaki. Mediasi disini dilakukan masuk dalam peraturan PERMA yang dilakukan di dalam pengadilan. Mediator yang dapat melaksanakan mediasi adalah hakim mediator yang sudah mempunyai sertifikat mediator. Berkenaan dengan proses mediasi di Pengadilan, ketentuan dalam Pasal 3 ayat (1) PERMA No. 1 Tahun 2016 menentukan, bahwa"

Setiap hakim, mediator dan para pihak atau kuasa hukum wajib mengikuti prosedur penyelesaian sengketa melalui mediasi."

Jadi, proses mediasi yang dilakukan di Pengadilan harus tunduk dan mengikuti aturanaturan yang terdapat dalam PERMA No. 1 Tahun 2016 Sementara itu di Pengadilan Agama Ciamis kelas 1-A hanya ada 1 orang hakim yang mempunyai sertifikat tersebut yaitu bapak Drs. Oman S.Ag.

\section{Hasil Yang di Capai dalam Mediasi}

Dalam tahapan akhir mediasi, setelah proses mediasi sudah selesai dilaksanakan, mediator harus menyerahkan laporan hasil mediasi kepada ketua majelis hakim. Hasil akhir dari proses mediasi di Pengadilan Agama Ciamis ada beberapa kemungkinan, yaitu:

1) Mediasi berhasil

Mediasi dikatakan berhasil apabila kedua belah pihak yang berkerkara mau berdamai dan berstu kembali. Setelah itu mediator menghadap kepada majelis hakim untuk memberitahukan telah terjadi kesepakatan perdamaian, kemudian majelis hakim membuatkan akta perdamaian yang ditanda tangani kedua belah pihak dan gugatan perkara dicabut.

2) Mediasi tidak berhasil

Mediasi dikatakan tidak berhasil apabila kedua belah pihak tidak dapat dirukunkan kembali, dalam kata lain sudah bertekad untuk bercerai. Padahal mediator sudah melaksanakan mediasi sebagaimana mana mestinya, lalu dilanjutkan kepada sidang perkara perceraian.

3) Mediasi Gagal

Dikatakan gagal apabila mediasi tidak jadi dilaksanakan dikarena kan kedua belah pihak tidak dating dalam proses mediasi tersebut, selanjutnya sidang perkara perceraian dilanjutkan.

\section{Faktor Pendukung dan kendala dari Mediasi}

1. Faktor Pendukung 
Keberhasilan mediasi di Pengadilan Agama Ciamis masih sangat minim Berdasarkan data hasil mediasi yang berhasil yang peneliti dapatkan hanya 3,45\% sedangkan mediasi yang tidak berhasil maupun gagal mecapai 96,55\% dari keseluruhan mediasi yang berperkara pada tahun 2017. Berikut penulis paparkan faktor pendukung dan penghambat yang mempengaruhi keberhasilan mediasi

a. Kemampuan mediator

Hakim mediator di Pengadilan Agama Ciamis sudah memiliki sertifikat mediator dari BP4 (Badan Penasihat Pembinaan dan Perkawinan). Selain bersetifikasi beliau mempunyai kemampuan mengelola konflik para pihak dan bisa berkomunikasi dengan baik akan mudah membuat para pihak untuk kembali berdamai. Serta dibutuhkan juga kejelian mediator untuk mengungkapkan apakah permasalahan diantara para pihak dan kebjijaksanaan mediator dalam memberikan solusi, sehingga para pihak dapat menyelesaikan masalahnya dengan baik dan damai. Oleh sebab itu kemampuan mediator sangat berpengaruh kepada berhasil atau tidaknya mediasi tersebut.

b. Faktor psikologis seseorang

Setelah diadakannya mediasi kondisi psikologi seseorang bisa berubah-ubah. Dalam hal ini, mediator harus mengeluarkan keahliannya ketika proses mediasi. Seseorang yang ingin berpisah dengan pasangannya, mediator harus menyampaikan mengenai hal-hal yang dapat menimbulkan kembali rasa sayang para pihak, sehingga para pihak bisa merasakan rasa sayang yang masih ada diantara mereka dan saling membutuhkan satu sama lain, dengan begitu para pihak tidak jadi berpisah dapat kembali bersama dengan damai.

c. Iktikad baik kedua belah pihak

Saat proses mediasi berlangsung, mediator berperan sebagai penengah yang berusaha mendamaikan para pihak. Namun sebaik dan semaksimal apapun usaha yang dilakukan mediator dalam mendamaikan tidak akan berhasil jika tidak didukung dengan iktikad baik para pihak untuk rukun serta kesadaran masing-masing para pihak akan kekurangannya sehingga dapat saling memaafkan dan memulai hidup rukun kembali.

\section{KESIMPULAN}

Berdasarkan uraian dan pembahasan yang telah dijelaskan pada bab-bab sebelumnya, dan analisis data yang telah penulis uraikan pada bab IV sesuai dengan hasil penelitian lapangan serta di dukung dengan teori dari buku-buku. Maka pada bab ini penulis ingin menyimpulkan hasil dari penelitian yang penulis lakukan mengenai pelaksanaan mediasi di Pengadilan Agama Ciamis kelas 1-A tidak berjalan efektif sebagai upaya preventif dalam mencegah terjadinya perceraian. Mediasi yang dilakukan di Pengadilan Agama sudah sesuai aturan yang berlaku tetapi masih minimnya pengetahuan masyarakat terhadap manfaat dari mediasi sehingga perceraian tidak dapat dicegah. Adapun faktor pendukung dan penghambat dalam proses mediasi tersebut di dominasi oleh kendala yang dihadapi mediator.

\section{DAFTAR PUSTAKA}

Abbas Syahrizal. 2009. Mediasi: Dalam Perspektif Hukum Syariah, Hukum Adat, dan Hukum Nasional cet I. Kencana Prenada Media: Jakarta.

Abd. Rahman Ghazaly, 2015. Fikh Munakahat, Kencana: Jakarta.

Adies Putra Arba, Efektifitas Mediasi dalam Perkara Perceraian di Pengadilan Negri (studi di Pengadilan Negri Yogyakarta), skripsi (Yogyakarta : Universitas Islam Sunan Kalijaga, 2015)

Al-Bani Nasharuddin M. 2005. Shahih Sunan Abu Daud jilid 2. Pustaka Azzam: Jakarta. Amriani Nurnaningsih, 2012. Mediasi Alternatif Penyelesaian Sengketa di Pengadilan, Jakarta: Rajawali Press. 
Arto Mukti, 2007. Parktek Perkara Perdata Pada Peradilan Agama, cet. 7 Yogyakarta: Pustaka Pelajar

Buku Nikah, Departemen Agama RI, Tahun 1999

Departemen Agama RI, Syaamil. 2013. Al-Quran dan Terjemahnya, Jakarta: Qisthi Pers.

Diponegoro Muhammad Ahmad. 2011. Konseling Islami. Gala Ilmu Semesta: Yogyakarta.

Munawwir Ahmad Warson, 1997. Kamus Arab-Indonesia Terlengkap. Surabaya: Pustaka Progresif.

Nurihsan Juntika Achmad. 2011. Bimbingan Dan Konseling Dalam Berbagai Latar Kehidupan. Refika Aditama: Bandung.

Pawito. 2007. Penelitiana Komunikasi Kualitatif. LkiS: Yogyakarta

Prayitno, 2004. Dasar-Dasar Bimbingan dan Konseling, Jakarta: PT Renika Cipta

Prayitno, 2012. Jenis Layanan dan Kegiatan Pendukung Konselin. UNP: Padang.

S. Nasution. 1996. Metode Naturalistik Kualitatif. Tarsitno: Bandung.

Sabiq Sayyid. 1990. Fiqh al-Sunnah Juz 2. Kairo: Dar al-Fath.

Takdir Rahmadi, 2010 Mediasi Penyelesaian Sengketa Melalui Pendekatan Mufakat, Jakarta:

Raja Grafindo Persada.

Tim Redaksi, 2008. Kamus Besar bahasa Indonesia Pusat bahasa (Edisi ke IV, Jakarta: PT Gramedia Pustaka Utama.

Tohirin, 2013. Bimbingan dan Konseling di Sekolah dan Madrasah (Berbasis SIntegritas),Ed. Revisi 5, Jakarta: Rajawali Pers. 